\title{
Vízbiztonság - önkormányzati/ települési éghajlati adaptációs célú vízmegtartó objektumok létesítése
}

\section{Water Security - Implementing of Water Retention Facilities for Climate Adaptation by Municipalities/Settlements}

A szerző célja, hogy bemutassa az éghajlati alkalmazkodás céljából tervezett természetes vízmegtartó intézkedések jelentőségét és létrehozásának lépéseit a döntéshozás szakmai hátterének és felelöseinek bemutatásával. Vizsgálja a jelenlegi vízbiztonsági és monitoring-elöírások relevanciáját egy lehetséges ég hajlati alkalmazkodási célú vízmegtartó létesítményre, illetve a vízbiztonságot célzó intézkedések hatékonyságát.

Kulcsszavak: éghajlati adaptáció, vízbiztonság, helyi szintü döntéshozás, vízmegtartás, monitorozás

The aim of the author is to present the importance and steps of establishing natural water retention facilities designed for climate adaptation by presenting the professional background and the decision-makers. The study examines what water safety and monitoring standards apply to a water retention facility for climate adaptation and whether the extent of water safety is satisfactory.

Keywords: climate adaptation, water security, local decision-making, water retention, monitoring

\section{Bevezetés}

A Katonai Müszaki Doktori Iskolában folytatott tanulmányaim és kutatási témám - az éghajlatváltozás hatása a felszín alatti vízbázisok természetes visszapótlódására - összefüggenek ezzel a területtel. Mára az éghajlatváltozás vízbiztonsági aspektusai komoly kockázattá váltak mind

Országos Vizügyi Főigazgatóság, nemzetközi projekt koordinátor, HHK Katonai Müszaki Doktori Iskola doktorandusz, e-mail: lakatos.boglarka@ovf.hu, ORCID: https://orcid.org/0000-0001-7760-3190 
ellátási, mind védelmi szempontból. A Hadtudományi és Honvédtisztképző Kar ehhez kapcsolódó kutatásainak eredményeit felhasználva folytatom ennek a sajátos területnek a feltárását.

A tanulmány tartalma önállóan is értelmezhető, de folytatásos céllal íródott az Éghajlati adaptáció vízmegtartással című munkámra, amelyben az éghajlatváltozásra való felkészülést és alkalmazkodást, illetve a kockázatcsökkentéssel kapcsolatos módszereket tártam fel. A jelenlegi tanulmány célja ezeknek a kifejezetten természetes vízmegtartással kapcsolatos adaptációs intézkedések konkrét megvalósításának lépéseit bemutatni.

Az éghajlatváltozás globális folyamat, hatásai azonban a helyi közösségeket érintik. A veszélyek különféle szélsőséges időjárási eseményekben nyilvánulnak meg, a leggyakoribb problémát azonban a víz hiánya vagy túlzott mennyisége okozza. A klimatikus változás folyamata jelentős hatást gyakorolhat a hazai vízgazdálkodásra. A jelenlegi előrejelzések szerint a felszíni lefolyás időben átrendeződik, a téli időszak nagyobb csapadéka és a korai olvadás miatt az árhullámok zöme a téli, kora tavaszi időszakra fog összpontosulni, a nyár végi, őszi lefolyás várhatóan csökkeni fog. Az éghajlatváltozás további következménye a nagy intenzitású csapadékesemények gyakoriságának növekedése, amelyek növelik a helyi vízkáreseményeket is. A szokásos tavaszi és őszi árvíz mellett a legváratlanabb időpontokban is fel kell készülni hirtelen, jelentős árhullámokra. ${ }^{2}$

Magyarországon az átlaghőmérséklet emelkedése várható, növekednek a vízhiányos és aszályos időszakok, miközben a lehulló csapadék mennyisége, eloszlása és intenzitása egyre kiszámíthatatlanabbá válik, súlyosbodó árvíz- és belvízproblémákat okozva. A vízbiztonság definíciója a vízgazdálkodással foglalkozó szervezetek tevékenységét koordináló ENSZ-szervezet szerint: „A társadalom képessége az életfenntartáshoz, az emberi jóléthez és a társadalmi-gazdasági fejlődéshez szükséges mennyiségű és elfogadható minőségű víz fenntartható biztosításához, a vízszennyezés és a víztől függő katasztrófák elleni védekezésre és az ökológiai rendszerek megőrzésére béke és politikai stabilitás viszonyai között."3 A vízgazdálkodás intézményére és a vízgazdálkodási tevékenységekre tehát nagy felelősség hárul.

Alvízi országként különösen nagy figyelmet kell fordítani a vízbiztonságra és biztonságos vízfenntartására. Ennek egyik eszköze a víz megtartása, ezen belül pedig a természetes vízmegtartó intézkedések előmozdítása. A természetes vízmegtartó létesítmények hozzájárulnak a biztonsághoz, tekintettel arra, hogy természetes élővizeink utánpótlása külföldről érkezik, és a vízgyűjtő területeken bekövetkező tartós csapadékhiány vízhozamcsökkenést eredményez, amelynek társadalmi, gazdasági hatásai is lehetnek.

Számos országban a vízhasználat jelenleg is állandó konfliktusforrás. Hazánk nincs ilyen helyzetben, de Magyarország kitettsége ezeknek a külső tényezőknek és függése a szomszédos országoktól világossá teszi azt, hogy krízishelyzetben függünk mások jóindulatától, és egy

2 Halász László - Földi László: Az éghajlatváltozás hatása a természeti katasztrófákra. In Földi László - Hegedűs Hajnalka (szerk.): Adaptációs lehetőségek az éghajlatváltozás következményeihez a közszolgálat területén. Budapest, Nemzeti Közszolgálati Egyetem, 2019. 386-412.

3 UN Water [vízgazdálkodással foglalkozó szervezetek tevékenységét koordináló Egyesült Nemzetek Szövetségéhez tartozó alszervezet] Annual Report. 2013. Elérhető: www.unwater.org/publications/un-water-annual-report-2013/ (A letöltés dátuma: 2020. 11. 24.) 
esetlegesen bekövetkező vízhozamcsökkenés esetén minden kormány a saját érdekét fogja szem előtt tartani. ${ }^{4}$

Az árvízvédelmi művek, töltések, gátak, duzzasztógátak vizet tartanak meg kifejezetten árvízvédekezés, vagyis a lakosság életének és vagyonának megvédése céljából. Az emberre és környezetére nézve káros természeti folyamatok romboló hatásai ellen létesített nagy műszaki infrastruktúrák azonban konfliktusban állhatnak ökológiai érdekekkel, például a megváltozott környezeti viszonyokat elszenvedő vízi élölények egyedszámcsökkenése miatt, ami egyben a biodiverzitást is veszélyeztetheti. Egy vizes élőhely regenerálódása kifejezetten a helyi vízhez kötődő életközösségek kondíciójának javítására, visszaállítására irányul. Egy új rekreációs célú tó létesítése szintén a helyi életközösségeknek a javára, a biodiverzitás csökkenésének megállítására alkalmas a helyi lakosság szórakoztatása mellett.

Minden intézkedés saját céljának megfelelően jár el. A természetes vízmegtartó intézkedések kategóriája azonban nem egy új különálló csoportot képez, inkább egy olyan szemlélettel láttatja a meglévő műszaki és jogszabályi hátteret, amely az intézkedések integrációjával alakítja ki a win-win helyzetet. Az egy lokációban, városban, településen, vízgyűjtőn kezelendő problémákat ágazatonként és együtt is kezeli, így erősítve az oda-visszaható folyamatokat. A vízkészletek védelme és az éghajlatváltozáshoz kapcsolódó kockázatok kezelése szempontjából a természetes megközelítéseknek fontos szerepe van. E természetalapú megoldásokhoz kapcsolódó intézkedések célja a környezet, a talaj és a vízvezető rétegek vízmegtartó-képességének védelme és megerősítése az ökoszisztémák és a vízfolyások természetes sajátosságainak helyreállításán és fenntartásán, valamint a természetes folyamatok alkalmazásán keresztül, ezáltal csökkentve a vízkészletek éghajlatváltozás miatti sérülékenységét.

Tehát az eddigi ágazati beavatkozások most kicsit kiszélesítve látókörüket és hatókörüket további előnyökkel müködhetnek. Csökkenthetik az árvízveszélyt, miközben javítják a víz minőségét, fokozzák a szén-dioxid-elnyelést, miközben elősegítik a biológiai sokféleség megörzését és fenntartását. Szabályozzák a vízmegörzést, miközben javítják a vízhez való hozzáférés lehetőségét. Csökkentik az esővíz-gazdálkodáshoz szükséges költséges infrastruktúra iránti igényt, a táj képének javítása közben. Hüsítik és „zöldítik” a városokat, miközben kellemes környezetet biztosítanak azok lakosainak. Csökkenthetik az árvízzel veszélyeztetett területek arányát az Árvíz Irányelv célkitűzéseivel összhangban, illetve növelhetik a biológiai sokféleséget, és hozzájárulhatnak az EU Biodiverzitási Stratégiája célkitüzéseinek eléréséhez. A NÉS2 (Nemzeti Éghajlatváltozási Stratégia2) IV.7.2.-es fejezete szól a vízgazdálkodásról, amelyben már a rövid távú cselekvési irányoknál leírja a gyors vízelvezetésen alapuló vízrendezési gyakorlat helyetti vízvisszatartó vízrendezést, amelyek növelhetik a természeti rendszerek alkalmazkodási képességét, és hozzájárulhatnak az éghajlatváltozáshoz való alkalmazkodáshoz a vízhiány és az aszály együttes kezelésével. Hozzájárulhatnak a fenntartható várostervezéshez, és javíthatják a környezet minőségét, amelyben élünk. Ezenfelül a települési szennyvízkezelési irányelv, felszín alatti vizekről szóló irányelv, fenntartható erdőgazdálkodás, földhasználat mint erőforrás megvalósításához is hozzájárulhatnak.

4 Padányi József: Vízkonfliktusok. Hadtudomány, 25. (2015), Elektronikus különszám. 272-284. 


\section{A vízmegtartás irányelvi háttere}

A folyamatok és intézményrendszerek kusza hálójában kell először eligazodni ahhoz, hogy megértsük az alapvetően egyszerü, mégis hihetetlenül összetett vízzel kapcsolatos folyamatokat, feladatokat. A víz állami tulajdon, és így szinte az összes vízzel kapcsolatos tervezés és engedélyezés is közintézmények között zajlik. Az éghajlati adaptációt célzó intézkedések megtételéhez - amellett, hogy alulról jövő civil kezdeményezések is egyre többen vannak - alapvetően állami lépések szükségesek. Az európai uniós tagságunkkal együtt jár az EU-s stratégiák magyar jogrendbe illesztése és így a Víz Keretirányelv (VKI) hazai jogrendbe ültetése is, amelynek a Vízgyűjtő-Gazdálkodási Terv (VGT) felel meg. A VGT a VKI céljai szerint a víztestek azonosítása és állapotfelmérése után javasol intézkedéseket, amelyek a VKI hatályának lejártával is érvényesíthetők így. ${ }^{5}$ Ezenkívül többek között az Országgyűlés által 2008-ban elfogadott első Nemzeti Éghajlatváltozási Stratégia jogszabályi felülvizsgálatának eredményeképpen 2013-ban készült el a 2014-2025-re, kitekintéssel 2050-re vonatkozó második Nemzeti Éghajlatváltozási Stratégia tervezete (NÉS2). A stratégia magában foglalja az éghajlatváltozás várható magyarországi hatásainak, természeti és társadalmi-gazdasági következményeinek, valamint az ökoszisztémák és az ágazatok éghajlati sérülékenységének értékelését, az üvegházhatású gázok kibocsátásának 2050-ig tartó csökkentésére vonatkozó célokat, prioritásokat és cselekvési irányokat tartalmazó Hazai Dekarbonizációs Útitervet, valamint a Nemzeti Alkalmazkodási Stratégiát. Ez utóbbi fő célja az éghajlatváltozással és a klímabiztonsággal összefüggő kockázatok megelőzése, a károk mérséklése, valamint az éghajlatváltozás megelőzését, az éghajlatváltozásra való felkészülést és alkalmazkodást szolgáló szemléletformálási tevékenységek célrendszerének bemutatása és ágazati cselekvési irányok meghatározása az emberi egészség, a mezőgazdaság és vidékfejlesztés, a vízgazdálkodás, az erdészet, a természetvédelem, az energetikai infrastruktúra, a turizmus, a településügy és a katasztrófavédelem terén. ${ }^{6}$

\subsection{Felelösök, jogkörök és döntéshozók}

Jelenleg a Közfoglalkoztatási és Vízügyi Helyettes Államtitkárság gondoskodik többek között a vizek kártételei elleni védelem érdekében a vízkárelhárítási tevékenység megszervezéséről, irányításáról, ellenőrzéséről. Továbbá a helyi közfeladatokat meghaladó védekezésről, irányítja a vízgazdálkodási feladatok ellátását, az országos árvízvédekezést, a vízminőségi kárelhárítás végrehajtását, szakmai felügyeletet gyakorol a vízi társulatok felett, felügyeli a védekezés operatív irányítását, illetve a projektek irányítását. A vízügyi intézményrendszer tekintetében a Közfoglalkoztatási és Vízügyi Helyettes Államtitkárság közvetlen alárendeltségében létrehozták az Országos Vízügyi Főigazgatóságot, amely országos hatáskörü középirányítói szervként funkcionál, alárendeltségében 12 vízügyi igazgatósággal. ${ }^{7}$

2000/60/EK Víz Keretirányelv.

6 Második Nemzeti Éghajlatváltozási Stratégia. Innovációs és Technológiai Minisztérium, 2018. Elérhető: https:// nakfo.mbfsz.gov.hu/hu/node/517 (A letöltés dátuma: 2020. 03. 28.)

7 Belügyminisztérium, Közfoglalkoztatási és Vízügyi Helyettes Államtitkárság. Elérhető: https://2010-2014.kormany. hu/hu/belugyminiszterium/kozfoglalkoztatasi-helyettes-allamtitkarsag (A letöltés dátuma: 2020. 03. 28.) 
A 72/1996. (V. 22.) Korm. rendelet a vízgazdálkodási hatósági jogkör gyakorlásáról kifejti a vízügyi igazgatási szervek, valamint a helyi önkormányzatok jegyzőinek vízgazdálkodási hatósági hatáskörét és a hatósági jogkör gyakorlásának rendjét. Az 1995. évi LVII. törvény a vízgazdálkodásról, valamint az e rendeletben meghatározott vízgazdálkodással összefüggő elsőfokú vízügyi hatósági jogkört a területi vízügyi hatóság, a másodfokú vízügyi hatósági jogkört az országos vízügyi hatóság gyakorolja. Az általános közigazgatási rendtartásról szóló törvény szerinti felügyeleti szervként az országos vízügyi hatóság jár el. A helyi vízgazdálkodási hatósági jogkört első fokon a települési önkormányzat jegyzője, valamint - vízi társulat - hiányában a helyi közcélú vízilétesítmények, illetve közcélú vízimunkák költségeinek - külön jogszabály rendelkezései szerint - az érdekeltekre történő kivetésének jogát a járási hivatal, másodfokon a fővárosi és megyei kormányhivatal gyakorolja. Felügyeleti szervként a fővárosi és megyei kormányhivatal jár el. ${ }^{8}$

Tehát a hatósági jogkör a vízügyi igazgatóságoké, illetve az ő felettes szervük az Országos Vízügyi Főigazgatóság (OVF). Míg a helyi hatósági jogkör a település jegyzőjét illeti. Egy éghajlati adaptációs célú vízmegtartó intézkedéshez a szakmai irányát a felettes szervek és az általuk kiadott stratégiai dokumentumok jelentik. A kezdeményezés lehetősége azonban a helyi vezetőség kezében van. A nulladik lépés tehát a helyi vizek biztonságának fokozásához a hatályos helyi szervekkel, hatóságokkal és természetesen a helyi érintettekkel való szoros együttműködés.

Az önkormányzatok legfontosabb feladatait a helyi önkormányzatokról szóló 2011. évi CLXXXIX. törvény Magyarország helyi önkormányzatairól és az egyéb ágazati jogszabályok határozzák meg. Tartalmazza a települési önkormányzat feladatait: a település belterületén a csapadékvízzel történő gazdálkodás, a területi jelentőségű vízgazdálkodási, vízvédelmi feladatok, koncepciók egyeztetésére, véleményezésére területi és részvízgyűjtő hatáskörü, az országos jelentőségű vízgazdálkodási feladatok, koncepciók egyeztetésére, véleményezésére országos vízgazdálkodási tanácsot kell létrehozni. Az érintett jogszabály rendelkezése alapján a helyi közügyek, valamint a helyben biztosítható közfeladatok körében ellátandó helyi önkormányzati feladatok többek között a helyi környezet- és természetvédelem, vízgazdálkodás, vízkárelhárítás és a katasztrófavédelem. ${ }^{9}$

E feladatok némelyikénél szükség lenne az éghajlatváltozás figyelembevételére a fenntarthatóság és az eredményes adaptáció biztosítása érdekében. Példaként a településfejlesztés, a területrendezés, a regionális fejlesztés, a környezetvédelem, a természetvédelem, a vízgazdálkodás, a közműszolgáltatások és a hulladékgazdálkodás említhető. Az éghajlatváltozás hatásainak mérséklése és a klímaadaptáció a jogszabályokban meghatározottak szerint nem tartoznak az önkormányzatok kötelezően ellátandó feladatai közé. Viszonylag kevés önkormányzat azonban önkéntes módon foglalkozik az éghajlatváltozás kérdéseivel. Ezen erőfeszítések során két szervezet segíti őket: a Magyarországi Éghajlatvédelmi Szövetség (20 tag), valamint a Klímabarát Települések Szövetsége (33 tag). A jogszabályi feladatmeghatározás ellenére a helyi önkormányzatok sokszor nincsenek tisztában a rendelkezésükre álló természeti értékekkel, amelyek segítséget jelenthetnének az éghajlatváltozáshoz való alkalmazkodásban.

72/1996. (V. 22.) Korm. rendelet a vízgazdálkodási hatósági jogkör gyakorlásáról.

2011. évi CLXXXIX. törvény Magyarország helyi önkormányzatairól. 
Ilyenek például a többnyire a települések külterületein megtalálható gyakran több kilométernyi csatorna és vízfolyás. Egyáltalán nem, vagy nem ők tartják számon az értékeik között a vizenyős területeket, az anyagnyerőhelyeket, az invazív növényekkel borított elhagyatott területeket; ugyanígy nem számolnak erőforrásként a szennyvízzel, a szennyvíztisztító telepekről kibocsátott technológiai vízzel vagy a településen lehulló esővízzel. Az egyes vízgyűjtőterületeken vagy régiókon belül az önkormányzatok és más érdekelt partnerek közötti hatékony együttmüködés hiányában nagy kihívást jelent olyan hatékony megoldásokat találni, amelyek hozzájárulhatnak a rezisztens, adaptív és fenntartható közösségek létrehozásához. Mivel a település környékén, illetve a környező vízgyüjtőterületen a területhasználat döntő tényező a vízzel összefüggő éghajlati sérülékenység szempontjából, külön problémát jelent, hogy az önkormányzatok nem ismerik a mezőgazdasági ellátólánc saját településükön tevékenykedő érdekelt szereplőit. ${ }^{10}$

\subsection{A helyi vízhiányból vagy víztöbbletből adódó problémák integrált kezelése}

Földrajzi, vízrajzi és települési adottságának megfelelően minden önkormányzatnak más szempontokat kell figyelembe vennie a természetes vízmegtartó intézkedések kiválasztásához. Megtervezését és megvalósítását saját szerepkörének és feladatainak és a területet körülvevő környezet jellegzetességein túl a helyi érdekeltek teljes körének meg kell feleltetni. A különböző szektorok integrált kezelésével egymást kiegészítve és kombinálva érheti el ugyanis a legoptimálisabb költség-haszon értéket. A természetes vízmegtartó intézkedések kulcsszerepet játszanak az éghajlati alkalmazkodásban, kiemelt szerepük van a helyi lakosság életkörülményeinek javításában, kedvez a helyi gazdálkodóknak, a környező természeti értékeknek, segít a biodiverzitás megtartásában és növelésében. A helyi vízügyi adottságok fenntarthatóbb, tudatosabb kezelésének első lépése ez.

Jelen cikk keretein belül most csak az éghajlatváltozás miatt megváltozott feltételek és igények kapcsolatát vizsgálom, hazai körülmények között. Ezenkívül ugyanis számos más tényező is (népsűrüség növekedése, ipari és energiaszektor vízigényei, települési vízgazdálkodás állapota, ivóvízellátás, szennyvízelvezetés fejlesztési igényei) sürgeti az integrált vízgazdálkodás mihamarabbi végrehajtását.

\subsubsection{Villámárvíz-kockázat dombvidéki területeken}

Az éghajlatváltozás miatt megnőtt a valószínűsége a szélsőséges időjárási eseményeknek, nevezetesen a hirtelen nagy mennyiségben lezúduló csapadéknak. Magyarország területének mintegy 55\%-án dombvidéki adottságok a jellemzők, ahol az éghajlatváltozásból adódó hirtelen lezúduló nagy mennyiségű csapadék okoz károkat. A síkvidékkel ellentétben itt igen rövid, egy-két órán belüli, heves, talajpusztulást előidéző lefolyások keletkezhetnek, nagy károkat okozva településeken, müszaki létesítményekben (utak, vasutak, lakóházak). Ez egyrészt abból adódik, hogy a dombvidéki vízfolyások a hirtelen megnövekedett vízmennyiséget nem

10 A LIFE-MICACC projekt projekt indokoltsága és háttere. 2017. Elérhető: https://vizmegtartomegoldasok.bm.hu/ hu/celok_eredmenyek/hatter (A letöltés dátuma: 2020. 04. 01.) 
tudják elvezetni, medrükből kilépve elöntik a környező területeket, másrészt a nagy intenzitású csapadékot vagy hirtelen olvadásból keletkező vizet a talaj felső rétege nem tudja befogadni, és a lepelszerűen lefolyó víz megbontja és a magával viszi a talajszemcséket. A dombvidéki települések, így Magyarország településeinek több mint fele esik magas villámárvíz-kockázati besorolás alá. A legnagyobb veszélyt az 5-10\%-nál nagyobb lejtésű területek jelentik, ahol intenzív mezőgazdasági művelésű dombvidéken találhatók.

A mezőgazdaság és azon belül is a növénytermesztés, amely a legjelentősebb hatást gyakorolja a környezeti elemekre (talaj, víz, élővilág). A mezőgazdaság módszere meghatározza a táj képét, a mezőgazdasági élőhely diverzitását is, és az éghajlati alkalmazkodásban is nagy szerepe van. A helyi lakosság és a környező települések biztonságának megteremtésében az extrém időjárásra való felkészülés fontos része a megelőzésnek. A helyes mezőgazdasági módszerek megválasztásával nemcsak az vízmegtartást érhetjük el, de ezzel, a talaj beszivárgó képességének megnövelésével csökkenthetjük az extrém csapadékok káros hatásait, amelyek már a lakott területeken és a szomszédos lejjebb fekvő területeken is jelentkeznek.

Az olyan szélsőséges időjárási események, mint a hirtelen lezúduló intenzív csapadék által kiváltott villámárvizek a talajeróziót felgyorsítják, és az intenzív nem megfelelő művelés miatt eleve leromlott talajszerkezettel rendelkező területeken a víz beszivárgása jelentősen csökkenhet a vegetációs időszakban. Azok a régiók, ahol a domborzati adottságok mellett az intenzíven mủvelt területek aránya magas, fokozottabban kitettek a villámárvizek hatásának. ${ }^{11}$

A lakott területek megfelelő kialakítása azonban ugyanolyan fontos a biztonság és az alkalmazkodás megteremtésében. Az épületek, építmények, burkolt felületek területfoglalása miatt ugyanis jelentősen megváltoznak a vízháztartási viszonyok is. A beépített, burkolt felületeken a beszivárgás lokálisan megszűnik, a lefolyási tényező kedvezőtlenebbé válik, és ennek együttes hatása miatt az összegyülekezési idő rövidülése - ugyanakkora csapadék mellett is - az árvizek hozamának növekedését okozza. A folyók felé terjeszkedő települések, nem ritkán az árvízvédelmi töltéseken belüli házsorok rontják az árvíz levezetését, továbbá ezeknek a településrészeknek a megvédése árvíz idején rendkívüli erőfeszítést, esetenként a mentett értéket messze meghaladó ráfordítást igényel.

A dombvidéki területeken még fennmaradt természetes élőhelyek, így a biológiai sokféleség csökkenése és az ökoszisztéma-szolgáltatások további hanyatlásának megállítására is figyelmet kell fordítani. A lakosság és az épített környezet, a mezőgazdasági és erdőgazdasági területek igényei, illetve a természeti környezet érdekeit szükséges együtt kezelni, így a villámárvíz-kockázat csökkentése és az aszály hatásainak mérséklése is megvalósulhat.

Ugyanez a problémakör síkvidéki területeken aszály, belvíz, süllyedő talajvízszint, elsivatagosodás, biodiverzitás-csökkenés formájában érzékelhető és mérhető. Hosszú távon jelentős ökológiai és gazdasági probléma az aszály, de az egyéb időjárási szélsőségek, például a hirtelen, özönvízszerű esőzések is óriási gondot okoznak. A klímaváltozás következtében ezek egyre

11 Jakab Gergely et al.: Spatial analysis of changes and anomalies of intense rainfalls in Hungary. Hungarian Geographical Bulletin, 68. (2019), 3. 241-253. 
gyakrabban fordulnak elő világszerte és hazánkban egyaránt. Az aszály, valamint az öntözés hiányának a mezőgazdasági termelékenységre kifejtett hatása szembeötlő. ${ }^{12}$

A mezőgazdasági ágazatban a belvizes és a vízhiányos időszakok váltakozása okoz problémát. A belvíz hatása többek között a terméshozam csökkenésében és a talajtermékenység romlásában jelentkezik elsősorban, de hosszú távon az elöntések hatására végbemenő káros hatások éveken keresztül visszafoghatják az adott terület termékenységét. A talajszerkezeti degradáció pedig növeli az aszályérzékenységet. ${ }^{13}$

Emiatt egyre jobban előtérbe kerül a belvízgazdálkodás. Lényege, hogy a vízrendezési művek célszerű üzemeltetésével a levezetés szabályozható, késleltethető, a belvizek medertározással, övgátolt legelőkön, belvíztározókban visszatarthatók. A belvízgazdálkodás a vízrendezési és a mezőgazdasági tevékenység egységes szemléletű alkalmazásával a belvizes és az aszályos időszakok kártételeinek csökkentésére egyaránt hatékony eszköz. A vizek újrahasznosíthatóságának alapkövetelménye a visszatartott, tározott víz megfelelő minősége. A magyar vízgazdálkodás kiemelt célja az országban visszatartott vízmennyiség növelése, ennek ellenére a csapadékvíz tudatos területi visszatartása többnyire nem vagy csak korlátozottan megoldott. A csapadékvíz-gazdálkodás és belvízgazdálkodás jó gyakorlatai nem vagy csak igen korlátozottan terjedtek el. A belterületi vízrendezés, -elvezetés feladatait az önkormányzatok maguk látják el, tapasztalat alapján megállapítható, hogy csak kevés önkormányzat esetében biztosított szervezeten belül a megfelelő végzettséggel rendelkező humán erőforrás.

Ha egy ökológiai rendszer fenntartása érdekében vízpótlásra van szükség, nemcsak a „menynyi?", hanem a „honnan?", a „milyen összetételű?", sőt a „mennyiért?" kérdésre is tudományosan megalapozott válaszokat kell adni. A nem megfelelő összetételű vízből származó vízpótlás tovább károsíthatja az életközösséget, a vízátvezetéssel pedig idegenhonos fajok juthatnak az élőhelyre. Ugyanakkor számos vízi ökoszisztéma esetében a konnektivitás biztosítása: hallépcsők, mederátvágások, ökológiai folyosók kialakítása lehet az elsődleges feladat. Őshonos, védett fajok vissza-, illetve betelepítése rehabilitációs, rekonstrukciós célból (esetleg invazív élőlények visszaszorítása érdekében) csak az ökoszisztéma egészére kifejtett hatásaik ismeretében lehetséges. A rehabilitációt nemcsak a víztestre, hanem a határos parti zónára, sőt akár az egész vízgyüjtőterületre tekintve kell megtervezni és kivitelezni. Ehhez szükséges lehet pufferzónák létrehozása, a területhasználat módosítása vagy megfelelő, például szennyezőanyagok és hirtelen csapadékhullámok visszatartásában is szerepet játszó növényborítás biztosítása. ${ }^{14}$

A városi vagy települési vízgazdálkodásnak ugyanúgy meg kell küzdenie az éghajlatváltozásból adódó egyre gyakoribb hőhullámokkal. További kihívást jelent az épített infrastruktúra védelme, árvízvédelme, a megfelelő csapadékgazdálkodása kialakítása, az ivóvízellátásának biztonsága, a zöldfelület arányának szabályzat szerinti betartása, illetve a szennyvíztisztítás

12 Berek Tamás: A víz, mint környezeti erőforrás a Kárpát-medencében, vízbázisok, vízbiztonság. In Krajnc Zoltán - Csengeri János (szerk.): A hadtudomány és a hadviselés komplexitása a XXI. században. Budapest, Nemzeti Közszolgálati Egyetem, 2015. 61-73.

13 Bíró Tibor: Amikor sok víz van a területen - Belvíz. Magyar Tudomány, 178. (2017), 10. 1216-1227.

14 A Nemzeti Víztudományi Kutatási Program kihívásai és feladatai. Magyar Tudományos Akadémia, Ökológiai Kutatóközpont Víztudományi Koordinációs Csoport, 2018. Elérhető: https://mta.hu/data/dokumentumok/ Viztudomanyi\%20Program/NVKP_20180331.pdf (A letöltés dátuma: 2020. 04. 04.) 
megoldása. A megfelelö éghajlati alkalmazkodáshoz még a közszolgálati, vízügyi területeken is törekedni kell a gazdasági szektorban elterjedt úgynevezett körforgásos gazdálkodás alapelveinek kialakítására, alkalmazására, amelyben a legfőbb tényező az újrahasználhatóság, az életciklus növelése. Néhány esetben a természetes vízmegtartó intézkedések fő szerepe a nagyszabású épített infrastruktúra kiegészítése lesz. Ez segít minimálisra csökkenteni az épített infrastruktúra méretét (és költségeit), és az épített infrastruktúra esetleges kedvezőtlen hatásait is minimálisra csökkenti vagy ellensúlyozza.

Az integrált kezelés tehát nem könnyű feladat. A végrehajtás szintjén szoros együttmüködés szükséges a vízzel közvetlenül foglalkozó vízgazdálkodási és más, a vizeinkre hatással lévő intézmények között. A területhasznosítás és -fejlesztés, a mezőgazdaság, az erdőgazdaság, a környezet- és természetvédelem, ipar és turizmus/szabadidő-eltöltés szakértőinek együttes tájékozottsága és együttműködése nélkül nem valósulhat meg integrált vízgazdálkodás, sem helyileg, sem nemzetközileg.

\subsubsection{Tájékozódási lehetőségek a települési adaptáció első lépéseihez}

Az éghajlati alkalmazkodás egy multidiszciplináris terület, a feljebb kifejtett integrált kezeléshez szakemberek egész csoportjára van szükség. Amikor azonban az anyagi keretek, szervezeti felépítés miatt vagy más egyéb okból kifolyólag nincs elegendő információja egy döntéshozónak, akkor más úton kell tájékozódni. A különböző hazai és nemzetközi keretprogramoknak köszönhetően erre is számos lehetőség adott ma már. A különböző szervezetek és programok arra hivatottak, hogy érthetővé és elérhetővé tegyék a legfontosabb éghajlatváltozással és vízbiztonsággal kapcsolatos információkat az érdeklődőknek, döntéshozói szinten is.

A Klímabarát Települések Szövetségének három kiadványában is megismerhetjük a klímaváltozással kapcsolatos teendők fontosságát, és nagy segítséget nyújtanak a megvalósításban is. Rendszeres és széles körű tájékoztatást (nyílt hozzáférésű honlap, közösségi oldal, szakmai kiadványok, Klímabarát Hírmondó) biztosítanak, jól kereshető tudásbázist építenek, képzési program és tananyag kidolgozásával és módszertani útmutató segítségével gyakorlati lépéseket sürgetnek, biztosítják szakértői hálózatukat, a hálózatépítést elősegítő és a különböző érdekeket képviselő felek közti dialógust ösztönző programok szervezését végzik. Elősegítik a nemzetközi projektek megvalósulását. ${ }^{15}$

Az ICLEI - Helyi Önkormányzatok a Fenntarthatóságért (ICLEI - Local Governments for Sustainability) több mint 1500, a fenntartható jövő megteremtése mellett elkötelezett város és régió vezető globális hálózata. A szervezet az Egyesült Nemzetek Szervezetének égisze alatt, de attól függetlenül jött létre. Jelenleg több mint 86 országban vannak tagjai a világ minden részéről. Az ICLEl technikai konzultációval, tréningekkel és információs szolgáltatásokkal segíti a tagok kapacitásépítését és az egymás közti tudásmegosztást, továbbá a helyi önkormányzatokat a lokális fenntartható fejlesztések megvalósításában támogatja. Alapelvének tekinti, hogy

15 Klímabarát Települések Szövetsége. Elérhető: www.klimabarat.hu/ (A letöltés dátuma: 2020. 04. 04.) 
a lokálisan tervezett és vezérelt kezdeményezések hatékony és költséghatékony módon tudják biztosítani a helyi, a nemzeti és a globális fenntarthatósági célok elérését. ${ }^{16}$

A Nemzeti Alkalmazkodási Központ Főosztály (NAKFO) a Magyar Bányászati és Földtani Szolgálat (MBFSZ) szervezeti egysége. Az MBFSZ a hazai klímapolitika tudományos háttérbázisaként közreműködik az ország nemzeti szintű éghajlatvédelmi feladatainak stratégiai megalapozásában, az éghajlatváltozás hazai hatásainak értékelésére vonatkozó módszertanok kifejlesztésében az önkormányzati éghajlatvédelmi tervezést és helyi alkalmazkodást támogató tevékenységek ellátásában. Többek között olyan programokkal segítik az önkormányzatok munkáját, mint a „Településvezetői Éghajlati Akadémia” című rendezvénysorozat. Ezenkívül a városi klímastratégiák kidolgozásához készített módszertani útmutató gyakorlati, hasznosítható segítséget nyújt a helyi önkormányzatok számára a klímastratégia kidolgozásához. ${ }^{17}$

Az Európai Bizottság 2015. október 15-én létrehozta a Polgármesterek új, egységesített Klíma- és Energiaügyi Szövetségét (Mayors Adapt - Polgármesterek Alkalmazkodnak). A szövetség három alappillért: a $\mathrm{CO}^{2}$-csökkentést, a klímaváltozáshoz való alkalmazkodást, valamint a biztonságos, fenntartható és elérhető energiát támogatja. Az aláíró városok elkötelezettek abban, hogy aktívan támogatják az EU azon célkitűzésének megvalósítását, miszerint 2030-ra az üvegházhatást okozó gázok mennyiségét 40\%-kal csökkenti, valamint vállalják, hogy a klímaváltozáshoz történő alkalmazkodást segítő intézkedéseket vezetnek be. Annak érdekében, hogy a politikai kötelezettségvállalást gyakorlati intézkedések és projektek kövessék, a szövetség aláíróinak ki kell dolgozniuk egy alap $\mathrm{CO}^{2}$-kibocsátási készletet, illetve egy klímaváltozási kockázat- és veszélyeztetettségértékelést. A felek vállalják, hogy a helyi közgyűlési határozattól számított két éven belül benyújtanak egy Fenntartható Energia- és Klímaakciótervet (SECAP - Sustainable Energy Action Plan), amelyben vázolják a végrehajtani kívánt legfontosabb tevékenységeket. Az alkalmazkodási stratégia a SECAP-módszertan része, a részstratégia az energia-akciótervvel együtt vagy különböző tervezési dokumentum(ok)ban is szerepeltethető. Ez a határozott kötelezettségvállalás egy hosszú távú folyamat kezdetét jelzi, amelynek során a településeknek és településközösségeknek kétévente jelenteniük kell, hogyan halad a cselekvési terv megvalósítása. ${ }^{18}$

Az európai uniós támogatási konstrukciók pályázati kiírásai esetében előnyt jelent, ha az önkormányzat rendelkezik akciótervvel. A Fenntartható Energia és Klímaakcióterv alapul szolgálhat például az ELENA (European Local Energy Assistance - Európai helyi energiahatékonysági támogatás), illetve a JESSICA (Joint European Support for Sustainable Investment in City Areas - Fenntartható városfejlesztési beruházásokat támogató közös európai kezdeményezés) finanszírozási támogatásának igénybevételéhez. A H2020 Smart City támogatások elnyerése

16 ICLEI-Local Governments for Sustainability. Wikipedia the Free Encyclopedia. Elérhető: https://en.wikipedia.org/ wiki/ICLEI (A letöltés dátuma: 2020. 04. 10.)

17 A Nemzeti Alkalmazkodási Központ Föosztályról. Elérhetö: http://nakfo.mbfsz.gov.hu/hu/node/29 (A letöltés dátuma: 2020. 04. 08.)

18 Alkalmazkodó Polgármesterek (Mayors Adapt) kezdeményezés ünnepélyes aláirási ceremóniája. Elérhető: www. eghajlatvedelmiszovetseg.hu/index.php/hirek/108-alkalmazkodo-polgarmesterek-mayors-adapt-kezdemenyezes-unnepelyes-alairasi-ceremoniaja (A letöltés dátuma: 2020. 04. 06.) 
során már előfeltételnek számít a SECAP (Sustainable Energy and Climate Action Plan - Fenntartható energia és éghajlati cselekvési terv) ${ }^{19}$ megléte.

\subsection{Eszközök és finanszírozás}

A vízmegtartó intézkedések finanszírozásához széles körü állami támogatások és európai uniós, alapok állnak rendelkezésre. A hazai forrásokat az operatív programok határozzák meg, ezek olyan részletes tervek, amelyekben a tagállamok meghatározzák, miképpen fogják elkölteni az európai strukturális és beruházási alapokból származó támogatást a programozási időszak során. A programok vagy egy konkrét régióra vagy egy egész országra kiterjedő tematikus célra (például a környezetvédelem) vonatkozhatnak. Az európai területi együttmüködés célkitűzés teljesítéséhez határon átnyúló vagy régiók közötti operatív programokat határoznak meg. Az Európai Bizottság által a programozási időszak kezdetén elfogadott operatív programok finanszírozása az Európai Regionális Fejlesztési Alap vagy a Kohéziós Alap keretében történik. ${ }^{20}$

A különböző ágazatok közül a természetes vízmegtartó intézkedések finanszírozására a Környezet- és Energetikai Hatékonysági Operatív Program (KEHOP) az egyik legfontosabb forrás, mivel a program célja a fenntartható növekedés támogatása, valamint hogy hozzájáruljon az Európa 2020 stratégia céljainak eléréséhez az intelligens, fenntartható és inkluzív növekedés érdekében. Javítaná az árvízvédelmet, valamint több lakos számára biztosítana jobb hulladék- és szennyvízgazdálkodási szolgáltatásokat és jó minőségű ivóvizet, segítene a természetes élőhelyek és fajok megóvásában, illetve javítaná az energiahatékonyságot és a megújuló energiaforrások felhasználását. A program öt fő prioritásra épül:

- Az éghajlatváltozás hatásaihoz való alkalmazkodás;

- A vízellátás, a szennyvízelvezetés és a szennyvíztisztítás, valamint a szennyvízgazdálkodás fejlesztése;

- Hulladékgazdálkodással és környezeti helyreállítással kapcsolatos fejlesztések;

- Természetvédelemmel és vadvédelemmel kapcsolatos fejlesztések;

- A jobb energiafelhasználás és a megújuló energiaforrások használatának előmozdítása.

A fenntartható fejlődés elősegítésére a fenti prioritásokat négy fő horizontális irányelv hatja át: A klímaváltozás kedvezőtlen hatásainak megelőzése és mérséklése, az alkalmazkodóképesség javítása, az erőforrás-felhasználás hatékonyságának fokozása, a szennyezések és terhelések megelőzése és mérséklése, illetve az egészséges és fenntartható környezet biztosítása. A klímaváltozás hatásaihoz való alkalmazkodást, valamint a természeti katasztrófák megelőzését szolgáló adat- és tudásbázis megteremtésének specifikus célkitűzései a vízkészletekkel történő fenntartható gazdálkodás feltételeinek javítása, az árvizek kártételei elleni védekezés feltételeinek javítása, illetve a lakosság személy- és vagyonbiztonságának növelése érdekében magasabb minőségü katasztrófavédelem.

19 P. Bertoldi (szerk.): Guidebook 'How to develop a Sustainable Energy and Climate Action Plan (SECAP)'. JRC Science for Policy Report, 2018.

20 Európai uniós regionális és nemzeti programok. Európai Bizottság. Elérhető: https://ec.europa.eu/regional_policy/ hu/atlas/programmes (A letöltés dátuma: 2020. 04. 13.) 
A KEHOP-pályázatok célcsoportjai prioritásonként változnak átfedésekkel. Az éghajlati alkalmazkodás föbb célcsoportjai a civil és nonprofit szervezetek, központi közigazgatási szervek, önkormányzatok, vízügyi igazgatási szervek, veszélyelhárításban dolgozó szervek. Az 5 föbb prioritás mindegyikében célcsoportonként szerepelnek az önkormányzatok. ${ }^{21}$

A közvetlen brüsszeli források közül az éghajlati adaptációt leginkább elősegítő projektek a 2014-2020-as pályázati időszakból többek között a LIFE pályázatok. Az alkalmazkodás az éghajlatváltozáshoz a LIFE Éghajlat-politikai Alprogram második kiemelt területe. Kiemelt feladata olyan projektötletek, új technológiák és módszerek, megoldások támogatása és összefogása, amelyek helyi, regionális és/vagy internacionális szinten járulnak hozzá a már légkörben lévő üvegházhatású gázok által kiváltott szélsőséges klíma- és időjárás-változáshoz való alkalmazkodáshoz.

Az éghajlatváltozáshoz való alkalmazkodás kiemelt területének konkrét célkitűzései az alkalmazkodással kapcsolatos uniós szakpolitika kidolgozásának és végrehajtásának elősegítése, ideértve az ökoszisztéma-alapú megközelítéseket is, amelyek a természetes vízmegtartó intézkedéseket és megoldásokat célozzák. Ezenkívül a hatékony éghajlatváltozáshoz való alkalmazkodási cselekvések és intézkedések kidolgozásához, felméréséhez, monitoringjához, értékeléséhez és végrehajtásához szükséges tudásalap javítása, illetve a cselekvési tervekre irányuló integrált megközelítések kidolgozásának és végrehajtásának elősegítése helyi, regionális vagy nemzeti szinten, adott esetben az ökoszisztéma-alapú megközelítések előtérbe helyezésével, amely szintén kifejezetten a lokális problémák megoldásának kidolgozásában segít. Ami pedig az egyik legfontosabb elvárás, a megismételhetőség, azaz az ismétlésre, átadásra vagy más területeken történő általános érvényesítésre alkalmas innovatív technológiák, rendszerek, módszerek és eszközök kifejlesztéséhez és demonstrációjához való hozzájárulás. Ez lehet kísérleti, demonstrációs vagy bevált gyakorlati projekt. ${ }^{22}$

\section{Vízmegtartásra szolgáló objektum kialakítása}

A fentiekben meghatározott szempontok szerint a problémakataszter felállítása után az ágazatok összehangolásával és a lehető legszéleskörübb megoldás és az ehhez kapcsolódó intézkedés kialakítása a soros. Érdemes meghatározni a kiterjedés nagyságrendjét, a problémák megoldásának lehetőleg teljes körü lefedéséhez, ugyanis a problémák továbbgyűrüzése elvén az alkalmazkodási intézkedéseknek a problémák kialakulásának okát célszerű megszüntetni. Tehát nemcsak egy intézkedésről lehet szó, hanem több egymáshoz kapcsolódó kisebbről is. A városi szintű tervezésnek szükséges figyelembe venni a vízgyűjtőszinten felmerülő igényeket is, mindezt szoros együttműködésben érdemes tárgyalni a szomszédos közvetlenül hatás alatt álló településekkel. A fentiekben leírt platformok tanulmányozásával még az alkalmazkodás témájában járatlan döntéshozók is fel tudják mérni az intézkedések nagyságát, összetettségét.

21 Környezeti és Energiahatékonyság Operatív Program. Elérhető: www.kehop.hu/kehop/ (A letöltés dátuma: 2020. 04. 12.)

22 LIFE Éghajlat-politikai Alprogram. Elérhető: www.lifepalyazatok.eu/home_hu.html?nyid=item20160505006 (A letöltés dátuma: 2020. 04. 12.) 


\subsection{Tervezés}

A térképek, birtokhatárok, érintettek igényei és a település lehetőségeinek elméleti számbavételezése és az intézkedésekről való döntés meghozása után a konkrét müszaki tervezést már az erre hivatott tervező szakemberek végzik. Ez ugyanis olyan szaktudást igénylő munkafázis, amelyben a műszaki elökészítés, műszaki ellenőrzés, a különböző szakértői munkálatok járnak együtt, mint például a geotechnikai, talajmechanikai, védőidom-meghatározás, környezetvédelmi hatástanulmányok. A környezetvédelmi szakmai anyagok készitése, a hatósági kötelezések és jogszabályi elöírások alapján elkészitendő felülvizsgálati, hatásvizsgálati, tényfeltáró dokumentációk, állapotfelmérés, kárelhárítási terv, engedélyezési eljárások lefolytatása, egyéb dokumentációk készítése, rekultivált hulladéklerakók utógondozási feladatainak elvégzése is idetartozik. Egy tervező szakember vagy -iroda ezeket a müszaki feladatokat, a projekt koordinációját és menedzselését elvégzik, és legtöbbször ebbe az engedélyezési folyamatok is beletartoznak, ami szintén összetett folyamat, de érdemes tisztában lenni a föbb állomásaival és típusaival. ${ }^{23}$

\subsection{Engedélyezés}

A 223/2014. (IX. 4.) vízügyi igazgatási és a vízügyi, valamint a vízvédelmi hatósági feladatokat ellátó szervek kijelöléséről szóló kormányrendeletben foglaltak szerint a vízügyi hatósági feladatokat 2014. szeptember 10-től a katasztrófavédelem látja el. A vízügyi és vízvédelmi hatósági és szakhatósági eljárásokat első fokon a területi vízügyi hatóságok, azaz a katasztrófavédelmi igazgatóságok speciális illetékességi területen folytatják le. Másodfokú vízügyi és vízvédelmi hatósági és szakhatósági hatáskörrel a BM Országos Katasztrófavédelmi Főigazgatóság rendelkezik. Ezen belül működik a Hatósági Főigazgató-helyettesi Szervezet, a Megelőzési és Engedélyezési Szolgálat és a Vízügyi és Vízvédelmi Főosztály. ${ }^{24}$

\subsubsection{Vízjogi engedély típusai}

Elvi vízjogi engedély: Az első lépcső az engedélyek igénylésének rendszerében az elvi vízjogi engedély, amely ugyan nem kötelező, de a nagyobb beruházások esetén érdemes igényelni, első fokon az illetékes megyei katasztrófavédelmi igazgatóságnál. Az elvi vízjogi engedély célja, hogy a vízügyi hatóság, még a beruházások megvalósitása előtt, azaz a tervezési szakaszban megvizsgálja, áttekinti a beruházó, tulajdonos által elképzelt vízi létesítményeket vagy egyéb vízhasználathoz köthetö beruházásokat. Fontos azonban szem előtt tartani, hogy a vízi munka elvégzésére, vízi létesítmény megépítésére, illetőleg vízhasználat gyakorlására nem jogosít.

Vízjogi létesítési engedély: Bármilyen vízi munka, így vízmegtartási célú létesítmény kivitelezése előtt a vízjogi létesítési engedélyt kell igényelni az illetékes vízügyi hatóságtól. Ebbe

23 Vizügyi tervezés és kivitelezés. Tenderterv Kft. Elérhető: www.tenderterv.hu/ (A letöltés dátuma: 2020. 04. 13.)

24 Vízügyi és vízvédelemi hatósági tevékenység. Belügyminisztérium, Országos Katasztrófavédelmi Főigazgatóság. Elérhető: www.katasztrofavedelem.hu/130/vzgyi-s-vzvdelemi-hatsgi-tevkenysg (A letöltés dátuma: 2020. 04. 13.) 
beletartozik a vízi létesítmény építése, átalakítása, de még a megszüntetése is. Az engedély igénylése a tulajdonos, építtető feladata.

Vízjogi üzemeltetési engedély: A különböző célú vízhasználatok megvalósításához, vízi létesítmény használatbavételéhez, üzemeltetéséhez és vízhasználathoz vízjogi üzemeltetési engedély szükséges. A vízjogi üzemeltetési engedélyt annak kell kérni, aki a vízhasználattal vagy a létesítmény üzemeltetésével járó jogokat és kötelezettségeket közvetlenül gyakorolja, illetve teljesíti (üzemeltet). A vízjogi üzemeltetési engedély a benne lefektetett feltételekkel és az üzemeltetéshez kötődő jogszabályokban, hatósági előírásokban megállapított kötelezettségek mellett feljogosít továbbá a vízi létesítmény használatbavételére. Az üzemeltetés céljából igényelt engedély kérelmében fel kell tüntetni a különbségeket a tervezett, illetve a már megvalósított vízlétesítmény között.

Vízjogi fennmaradási engedély: Az építésügyi hatóságtól kérhető fennmaradási engedély, abban az esetben, ha a vízi létesítmény építése, működtetése jogszerütlenül, azaz engedély nélkül vagy attól eltérően történt. Az építésügyi hatóság a tulajdonos számára adhat fennmaradási engedélyt.

Vízjogi megszüntetési engedélyeztetés: Engedéllyel rendelkező vízi létesítmény megszüntetése kizárólag vízjogi megszüntetési engedély birtokában végezhető, az abban foglaltak betartásával. A vízilétesítmény megszüntetéséhez szükséges vízjogi megszüntetési engedélyt a tulajdonos, a vagyonkezelő vagy a vízilétesítmény üzemeltetésével eddig járó jogokat és kötelezettségeket közvetlenül gyakorló köteles megszerezni.

\subsection{Vízügyi Objektum Azonosítás (VOR szám)}

A 72/1996. (V. 22.) Korm. rendelet rögzíti, hogy „valamennyi vízhasználat, vízimunka, vízilétesítmény esetén - elvi vízjogi és fennmaradási engedélynél az erre irányuló kérelemnél, vízhasználat önálló engedélyezése esetén a vízjogi üzemeltetési engedély iránti kérelemnél, különben a vízjogi létesítési engedély iránti kérelemnél - a vízügyi igazgatóság vízügyi objektumazonosítási nyilatkozata megléte" szükséges. Vízügyi Objektum Azonosító nyilatkozatot kell kérni a területileg illetékes vízügyi igazgatóságtól, ez az úgynevezett VOR szám. Ez segít a vízügyi igazgatóságnak az új objektumra kiadott engedély azonosításában és nyilvántartásában. ${ }^{25}$

Az objektumazonosítási nyilatkozat kiadására irányuló megkereséshez csatolni kell az engedélyezési tervdokumentációt - elvi vízjogi engedélyezés esetén a műszaki megoldást tartalmazó dokumentációt - és a vízjogi engedélyezés tárgyának megfelelő - az engedélyezési tervdokumentáció, illetve műszaki megoldást tartalmazó dokumentáció alapján kitöltött - létesítményazonosítási ürlapokat, amelyek Excel fájl formájában bármelyik vízügyi igazgatóság honlapjáról letölthetők A VOR szám igénylése elengedhetetlen a vízügyi hatósági és igazgatási eljárások, illetve a vízszolgáltatással kapcsolatos ügyintézés egységes rendszerben történő kezeléséhez. ${ }^{26}$

72/1996. (V. 22.) Korm. rendelet

26 41/2017. (XII. 29.) BM rendelet a vízjogi engedélyezési eljáráshoz szükséges dokumentáció tartalmáról. 


\subsection{Kivitelezés és üzemeltetés}

A kivitelezés után - amit a helyi adottságoktól kezdve az intézkedés típusán át, a szakemberek elérhetőségéig még rengeteg tényező befolyásolhat - az átadáson az önkormányzat megkezdheti az objektum üzemeltetését.

\subsection{Monitorozás}

A környezeti monitorozás feladatai közé tartozik a szennyezőanyagok keletkezésének feltárása, a globális környezeti változás hatása a környezet elemeire, a környezeti változások nyomon követésére készitett matematikai modellek paramétereinek az ellenőrzése, valamint az adatszolgáltatás a környezet-állapotértékeléshez. Vízrajzi monitoring alatt a vízzel kapcsolatos jellemzők (mennyiség, minőség) megfigyelésére alkalmas állomások hálózatát értjük. Felszíni, felszín közeli (talajvízkutak), felszín alatti (rétegvízkutak) és hidrometeorológiai állomásokon történnek a mérések.

A vízrajzi és vízminőségi tulajdonságokat országosan mérik fel az erre létesített megfigyelőhálózatok eszközei. A vízrajz megfigyeléséhez többek között a vízállás, vízhőmérséklet, vízsebesség, vízhozam, hordalékviszonyok, talajvízállás, rétegvízállás, források vízhozamának adatait gyűjtik. Ezenkívül a hidrometeorológiai mérések a csapadék, a levegö- és vízhőmérséklet, a talajnedvesség, páratartalom adatait figyelik. A magyarországi hidrológiai viszonyokat jellemző vízrajzi adatok észleltetését, az adatok gyűjtését, értékelését a területileg illetékes vízügyi igazgatóságok végzik az Országos Vízügyi Főigazgatóság koordinálásával. Az országos vízrajzi állomáshálózatot azoknak az észlelési elemeknek a mérésére hozták létre, amelyek mérése nemcsak szükséges, hanem országos előírás szerinti megbízhatósággal lehetséges is, az állomás megfelelő karbantartása és a mérés műszaki előírások technológiai szabályainak betartása mellett.

A vízrajzi észlelések és mérések az országos és regionális léptékủ áttekintést biztosító törzsállomásokon, valamint helyi üzemirányítási, illetve kutatási célú üzemi és tanulmányi állomásokon folynak. A törzshálózaton mért és észlelt adatok feldolgozása egységes elvek szerint történik. ${ }^{27}$

Egy új vízmegtartó objektum vízrajzi mérése abban az esetben lehetséges, ha van a közelében már telepített mérőállomás, amely így tagja a törzshálózatnak vagy az üzemeltető, ez esetben önkormányzat saját méréseivel.

A második Vízgyűjtő-gazdálkodási terv (2015) alapján a természetes medermorfológiai változások, illetve az emberi beavatkozások hatásainak viszonylag lassú időbeni lefolyása miatt a morfológiai monitoringvizsgálatokat elegendő hatévente elvégezni. A veszélyes anyagok vizsgálatát csak hatévente egyszer kell végezni, akkor azonban havi gyakoriságú mintákból. Létezik úgynevezett vizsgálati monitoring, amelyet akkor alkalmaznak, amikor ismerethiány miatt vagy rendkívüli esemény következményeinek kivizsgálására vagy az operatív monitoring ideiglenes helyettesítése miatt van szükség. Ez a módszer például célravezető lehet egy újonnan telepített vízmegtartásra szolgáló tározó tó esetében is.

27 Vizrajzi monitoring az Országos Vízügyi Igazgatóság hatáskörében. Elérhető: www.ovf.hu/hu/vizrajzi-monitoring (A letöltés dátuma: 2020. 04. 11.) 
A második Vízgyűjtő-gazdálkodási terv a felszín alatti vizekre vonatkozó VKI monitoringkövetelményének való megfelelés a 30/2004 (XII. 30.) KvVM rendelet a felszín alatti vizek vizsgálatának egyes szabályairól alapján történik. E szerint a felszín alatti monitoringrendszer két alrendszerből épül fel. Az egyik az állami és önkormányzati felelősségi körbe tartozó, a közérdek mértékével arányban álló részletességű és sủrüségü, úgynevezett területi (feltáró) monitoring, amely a következő főbb elemekből épül fel: a BM miniszter irányítása alá tartozó szervezetek által folyamatosan üzemeltetett rendszerek (pl. vízrajzi hálózat, rendszeresen vizsgált kutak), a speciális rendszerek (pl. távlati vízbázisok vízrajzi hálózatba nem tartozó kútjai), más állami szervezetek által folyamatosan üzemeltetett monitoringrendszerek, illetve települési önkormányzatok (elsősorban a városok) által végeztetett észlelések. Az egyes vízrajzi elemek észlelésének és mérésének szabályait egy műszaki előírás-sorozat (ME-10231-xx) tartalmazza. ${ }^{28}$

\subsection{Mintaterület}

A folyamatot jól demonstrálhatja egy olyan jellemzően dombvidéki település, ahol a tipikus éghajlatváltozással járó hirtelen nagy esőzésekből adódó ár- és iszapelöntésekkel küzdenek egyre gyakrabban. Ugyanezen a településen viszont megjelenik az éghajlatváltozás miatt erősödő nyári nagy hőhullámok trendje is, amely egészségügyileg veszélyezteti a lakosság egy részét, és amelyre szintén képes választ adni a vízmegtartás azáltal, hogy javítja a mikroklímát, hűti a közvetlen környezetét. A településhez közeli mezőgazdasági területeken csapadékszegény időszakokkal szembesülnek szinte minden évben. A természetes élőhelyek és a biológiai sokféleség csökkenése pedig országos jellegű probléma, így erre mindenképpen választ kell adni helyi szinten is. Ezenkívül a település sajátosságait, közeli ipari létesítményeinek fenntartható vízellátásáról is gondoskodni kell. Az előzőekben tárgyalt integrált kezelésnél tehát akkor érhetjük el a legjobb ár-érték arányt vagy az árhatékonyság-arányt, ha az egyes adaptációs intézkedéseket kombináljuk, úgy, mint például egy jól elhelyezett ideiglenes víztároló tó, amely segítheti a többletvíz tározását és egyben vízpótlást biztosít a száraz időszakokban.

Jelen cikk keretében kifejezetten a vízzel kapcsolatos intézkedéseket vizsgálva a nagy elöntések problémakörére válaszul adható megoldások kialakításának példájaként tudom említeni a Püspökszilágyon elvégzett intézkedéscsoportot. A helyi vízgyűjtő alsó és felső szakaszát egyaránt érintő integrált természetes vízmegtartó rendszer kialakításával mennek elébe a villámárvíz kárainak. A település célja az árhullámmal lezúduló víz és hordalék visszatartása a felső vízgyűjtőn, mielőtt az elérné az épített környezetet. A terméskő hordalékfogók állítják meg a hordalék- és iszapelöntéseket, és rönkgátat használnak a vízgyűjtő felső részén a csapadékvíz lassítására. Egy oldaltározó is segíti a csapadék helyben tartását. ${ }^{29}$

28 A Duna-vízgyűjtő magyarországi része Vízgyűjtő-Gazdálkodási Terv - 2015. Országos Vízügyi Főigazgatóság, 2016. Elérhető: www.vizugy.hu/vizstrategia/documents/E3E737A3-3EBC-4B6F-973C-5DD9B8A6DBAB/ OVGT_foanyag_vegleges.pdf (A letöltés dátuma: 2020. 04. 10.)

29 LIFE-MICACC projekt-Az önkormányzatok integráló és koordináló szerepének megerősítése az éghajlatváltozáshoz való alkalmazkodás érdekében - Püspökszilágyi mintaterület. Elérhető: https://vizmegtartomegoldasok.bm.hu/hu/ nwrm/5_pilotrol_reszletesen (A letöltés dátuma: 2020. 04. 01.) 


\section{Felmerülő kérdések egy éghajlati adaptációs célú természetes vízmegtartó létesítménynél}

A vízmegtartó létesítmények javíthatják a vízminőséget és csökkenthetik az árvízveszélyt, ugyanakkor az árvizes helyzeteket illetően fontos vízminőséget befolyásoló tényező az árhullám által szállított szennyeződés is, amelynek fenyegető kockázatával számolni kell.

Hazánk földrajzi helyzete miatt sérülékeny, ugyanis nagyfolyóink a határon kívül erednek, így a víz mennyiségét és minőségét elsősorban külföldi körülmények határozzák meg, ezekre kevés befolyással rendelkezünk. ${ }^{30}$

A vízmegtartó intézkedések különösen az alföldi tájakon a felszín alatti rétegvizek süllyedő szintjét is hivatottak ellensúlyozni, javítani. A felszíni és felszín alatti vizek kapcsolatrendszerét a földrajzi és domborzati viszonyokon túl a vízhasználat is jelentősen befolyásolja. Ez nem csak vízkivételkor igaz, de a víz visszapótlásakor ugyanígy. A csapadék helyben tartására szánt oldaltározók, lefolyáslassító, hordalékfogó mútárgyak segítik a beszivárgást, így befolyásolják a felszín alatti vizek mennyiségét és minőségét. Kérdés, mennyi idő alatt és milyen vízminőségi és mennyiségi változásra számíthatunk? Pontosan hogyan tudjuk monitorozni a fenntartható, biztonságos vízgazdálkodás és vízmegtartás érdekében az éghajlati alkalmazkodást és a települések sérülékenységének csökkentését szolgáló természetes létesítményeket? Erre ugyanis nincs egy egységes és átfogó iránymutatás a legfontosabb indikátorokra vonatkozóan, minden bizonnyal azok szerteágazó technikákat és rendszereket igénylő volta miatt is.

A beszivárgás elősegítése és a talajvízkészlet kiegyensúlyozásának pozitívumai mellett kérdés, hogy egy nyílt, akár csak időleges vízfelület milyen kockázatokat hordozhat a helyi ivóvízbázisokkal kapcsolatban? Elsősorban a mezőgazdasági és más ipari vagy lakossági eredetü szennyezés előfordulásának kockázatát szükséges figyelembe venni.

Azt is vizsgálni kell, hogy az adott vízmegtartó létesítmény a fenti szennyeződések kockázatával terhelve hatással lehet-e rövid vagy akár hosszú távon a helyi ivóvízellátásra. A létesítésnek tehát járulékos következménye kell hogy legyen a helyi vízmüre korábban elkészített vízbiztonsági terv felülvizsgálata. A vízbiztonsági terv ugyanakkor segíthet feltárni számos olyan tényezőt, amelyet kockázatként értékelni kell a kialakítandó vízmegtartó létesítményre is.

A vízellátás biztonságát fenyegető tényezők leírása és osztályozása ugyanis lehetővé teszi azok bekövetkezési valószínűségük alapján történő kategorizálásukat az értékelés szempontjából, hiszen nem az eseményjellegű veszélyes behatások számbavétele, hanem a hosszabb távon hatással bíró folyamatok felmérésére is sor kerül. ${ }^{31}$

Ez azonban közel sem ad minden kérdésre választ. A 123/1997. (VII. 18.) Korm. rendelet a vízbázisok, a távlati vízbázisok, valamint az ivóvízellátást szolgáló vízilétesítmények védelméről szól, amelyben leírja például a hidrogeológiai védőidom, védőövezet rendeltetését, amely a le nem bomló szennyezőanyagok elleni védelem, amelyet vagy a vízkivétel teljes utánpótlódási

30 Padányi József: Egyre kevesebb ivóvíz, egyre több katonai konfliktus. In Krajnc Zoltán - Csengeri, János (szerk.): A hadtudomány és a hadviselés komplexitása a XXI. században. Budapest, Nemzeti Közszolgálati Egyetem, 2015. 28-46.

31 Berek Tamás: A vízbiztonsági tervezés szerepe a fenntartható vízgazdálkodásban. Müszaki Katonai Közlöny, 26. (2016), 2. 32-48. 
területére (vízgyűjtőjére) vagy meghatározott részére kell kijelölni, és amely a szennyeződések ivóvízbázishoz jutását akadályozza. ${ }^{32}$ Az engedélyezési folyamatban a vízügyi hatóságok ezt a kérdést minden bizonnyal figyelembe veszik a VOR szám kiadása előtt, de mégis felvetődik a kérdés, hogy pontosan milyen biztonsági fokozat érvényes a természetes vízmegtartó intézkedések halmazára mind a kivitelezés, üzemeltetés fázisában, amely így a monitorozási és adatszolgáltatási tevékenységhez is kapcsolódik.

A település vagy város villámárvíz-kockázatának csökkentésére épített rönkgátak, a belvíz elvezetésére vagy egy helyre koncentrálására és így vízmegtartásra használt csatornák, az iszapelöntést gátló hordalékfogók esetében felmerül a kérdés, hogy a létesítmény vagy létesítménycsoportok kritikus infrastruktúráknak számítanak-e?

A 2012. évi CLXVI. a létfontosságú rendszerek és létesítmények azonosításáról, kijelöléséről és védelméről szóló törvényre vonatkozó 4. mellékletben a 2016. július 6-i (EU) 2016/1148 európai parlamenti és tanácsi irányelv szerinti ágazatok, illetve alágazatok megfeleltetésének táblázatában, a víz kategóriában az árvízi védművek, gátak szerepelnek. ${ }^{33}$ Eszerint egy fából készült rönkgát is minősülhet kritikus infrastruktúrának, amelyet így szükséges figyelembe venni a fenntartási és üzemeltetési gyakorlatban.

\section{Következtetések}

Nem lehet eléggé hangsúlyozni a helyi szintü intézkedések fontosságát, mivel a hazai vízügyi igazgatóságok és szakemberek is legjobb tudásuk szerint helyi vagy kisvízgyűjtő szintű problémákra tudnak választ adni különböző projektek keretében, amellett, hogy az integrált kezelést hangsúlyozva a Vízgyűjtő-gazdálkodási Terv újabb fejezetein dolgoznak. A települések vezetőinek felelőssége a biztonságos környezet, amelyben a vízbiztonság és a biztonságos víz alapfeltétel. Több kisebb rendszer fenntarthatóbb és könnyebben kezelhetőbb, „testreszabhatóbb”, mint egy nagy, így érdemes személetet váltani abban a kérdésben is, hogy a társadalmi felelősségvállalás önkormányzati szinten mire terjed ki jogszabályok, rendeletek és egyéb hivatalos hivatkozások nélkül is. Ehhez természetesen elengedhetetlen a megfelelő tájékoztatás a legfelsőbb felelős szervektől és a legújabb tudományos eredmények felhasználásával folyó fenntarthatóságot és a vízbiztonság jelentőségét hangsúlyozó szakmai továbbképzések, kifejezetten városvezetési döntéshozók körében.

A fenntartható, víztakarékos helyi vízgazdálkodás és csapadékgazdálkodás legoptimálisabb módszereinek kiválasztásában a megfelelő és integrált tervezés után az egyik legfontosabb kérdés a valódi hatás volumene és relatív gyorsasága. Az általános stratégiák ellenére még gyerekcipőben járnak a helyi víz- és csapadékgazdálkodási intézkedések. A vízügyi jogszabályok és rendeletek külön nem térnek ki ezeknek a létesítményeknek az ajánlott megfigyelési rend-

32 123/1997. (VII. 18.) Korm. rendelet a vízbázisok, a távlati vízbázisok, valamint az ivóvízellátást szolgáló vízilétesítmények védelméről.

33 2012. évi CLXVI. törvény a létfontosságú rendszerek és létesítmények azonosításáról, kijelöléséről és védelméröl. 
szereire. Az általános környezeti hatásokból, mint a párolgás változása, helyi ökoszisztémára való hatása, a mikroklíma javulása, a mezőgazdasági területek talajtulajdonságainak változása, esetleges javulása és így a kultúrnövények terméshozamában elért eredmények mind akkor bizonyíthatók, ha adatokkal tudjuk alátámasztani. A pozitív hatás mindenképp várható, de tovább optimalizálható ezeknek a természetes beavatkozásoknak a hatásfoka, ha pontosabban tudjuk megmondani, hogy mekkora az az aránypár a megtartott vízmennyiség és a gazdasági és ökoszisztéma-szolgáltatások között, ami korrelál az intézkedésbe fektetett anyagi ráfordítással. További kutatási téma az „alternatív” nem műszeres monitoring például a természetes indikátorok alkalmazása, amelyek a víz és a levegő minőségét, a biodiverzitás összetettségét jelezhetik. Ahhoz, hogy a kitüzött fenntarthatósági és biztonsági célok megvalósulásának folyamata követhető és értékelhető legyen, a válaszlépések hatékonysága érdekében, nagy szükség van a folyamatok megfigyelésére, a monitoringalapú fejlesztésekre és az erre való kötelezésre.

\section{Felhasznált irodalom}

Berek Tamás: A vízbiztonsági tervezés szerepe a fenntartható vízgazdálkodásban. Müszaki Katonai Közlöny, 26. (2016), 2. 32-48.

Berek Tamás: A víz, mint környezeti erőforrás a Kárpát-medencében, vízbázisok, vízbiztonság. In Krajnc Zoltán - Csengeri János (szerk.): A hadtudomány és a hadviselés komplexitása a XXI. században. Budapest, Nemzeti Közszolgálati Egyetem, 2015. 61-73.

Bertoldi, P. (szerk.): Guidebook 'How to develop a Sustainable Energy and Climate Action Plan (SECAP)'. JRC Science for Policy Report, 2018.

Bíró Tibor: Amikor sok víz van a területen - Belvíz. Magyar Tudomány, 178. (2017), 10. 1216-1227. DOI: https://doi.org/10.1556/2065.178.2017.10.5

Halász László - Földi László: Az éghajlatváltozás hatása a természeti katasztrófákra. In Földi László Hegedűs, Hajnalka (szerk.): Adaptációs lehetőségek az éghajlatváltozás következményeihez a közszolgálat területén. Budapest, Nemzeti Közszolgálati Egyetem, 2019. 386-412.

Jakab, Gergely - Tibor Bíró - Zoltán Kovács - Ádám Papp: Spatial analysis of changes and anomalies of intense rainfalls in Hungary. Hungarian Geographical Bulletin, 68. (2019), 3. 241-253. DOI: https://doi.org/10.15201/hungeobull.68.3.3

Padányi József: Egyre kevesebb ivóvíz, egyre több katonai konfliktus. In Krajnc Zoltán - Csengeri, János (szerk.): A hadtudomány és a hadviselés komplexitása a XXI. században. Budapest, Nemzeti Közszolgálati Egyetem, 2015. 28-46.

Padányi József: Vízkonfliktusok. Hadtudomány, 25. (2015), Elektronikus különszám. 272-284. DOI: https://doi.org/10.17047/HADTUD.2015.25.E.272

\section{Jogi források}

2011. évi CLXXXIX. törvény Magyarország helyi önkormányzatairól

2012. évi CLXVI. törvény a létfontosságú rendszerek és létesítmények azonosításáról, kijelöléséröl és védelméröl

2000/60/EK Víz Keretirányelv

41/2017. (XII. 29.) BM rendelet a vízjogi engedélyezési eljáráshoz szükséges dokumentáció tartalmáról

72/1996. (V. 22.) Korm. rendelet a vízgazdálkodási hatósági jogkör gyakorlásáról 
123/1997. (VII. 18.) Korm. rendelet a vízbázisok, a távlati vízbázisok, valamint az ivóvízellátást szolgáló vízilétesítmények védelméröl

65/2013. (III. 8.) Korm. rendelet a létfontosságú rendszerek és létesítmények azonosításáról, kijelöléséről és védelméről szóló 2012. évi CLXVI. törvény végrehajtásáról

\section{Internetes források}

Belügyminisztérium, Közfoglalkoztatási és Vízügyi Helyettes Államtitkárság. Elérhető: https://2010-2014 kormany.hu/hu/belugyminiszterium/kozfoglalkoztatasi-helyettes-allamtitkarsag (A letöltés dátuma: 2020. 03. 28.)

A Duna-vizgyüjtö magyarországi része Vízgyüjtö-Gazdálkodási Terv-2015. Országos Vízügyi Főigazgatóság, 2016. Elérhetö: www.vizugy.hu/vizstrategia/documents/E3E737A3-3EBC-4B6F-973C-5DD9B8A6DBAB/OVGT_foanyag_vegleges.pdf (A letöltés dátuma: 2020. 04. 10.)

Európai Unió regionális és nemzeti programok. Európai Bizottság. Elérhető: https://ec.europa.eu/regional_policy/hu/atlas/programmes (A letöltés dátuma: 2020. 04.13.)

Éghajlatvédelmi Szövetség tevékenysége. Alkalmazkodó Polgármesterek (Mayors Adapt) kezdeményezés ünnepélyes aláirási ceremóniája. Elérhető: www.eghajlatvedelmiszovetseg.hu/index.php/ hirek/108-alkalmazkodo-polgarmesterek-mayors-adapt-kezdemenyezes-unnepelyes-alairasi-ceremoniaja (A letöltés dátuma: 2020. 04. 06.)

Klímabarát Települések Szövetsége. Elérhető: www.klimabarat.hu/ (A letöltés dátuma: 2020. 04. 04.)

Környezeti és Energiahatékonyság Operatív Program. Elérhető: www.kehop.hu/kehop/ (A letöltés dátuma: 2020. 04. 12.)

A LIFE-MICACC projekt indokoltsága és háttere. 2017. Elérhető: https://vizmegtartomegoldasok.bm.hu/ hu/celok_eredmenyek/hatter (A letöltés dátuma: 2020. 04. 01.)

LIFE-MICACC projekt - Az önkormányzatok integráló és koordináló szerepének megerősítése az éghajlatváltozáshoz való alkalmazkodás érdekében - Püspökszilágyi mintaterület. Elérhetö: https://vizmegtartomegoldasok.bm.hu/hu/nwrm/5_pilotrol_reszletesen (A letöltés dátuma: 2020. 04. 01.)

LIFE Éghajlat-politikai Alprogram. Elérhető: www.lifepalyazatok.eu/home_hu.html?nyid=item201 60505006 (A letöltés dátuma: 2020. 04. 12.)

ICLEI - Local Governments for Sustainability. Wikipedia the Free Encyclopedia. Elérhetö: https://en.wikipedia.org/wiki/ICLEl (A letöltés dátuma: 2020. 04. 10.)

Második Nemzeti Éghajlatváltozási Stratégia. Innovációs és Technológiai Minisztérium, 2018. Elérhető: https://nakfo.mbfsz.gov.hu/hu/node/517 (A letöltés dátuma: 2020. 03. 28.)

A Nemzeti Alkalmazkodási Központ Föoszályról. Elérhető: http://nakfo.mbfsz.gov.hu/hu/node/29 (A letöltés dátuma: 2020. 04. 08.)

A Nemzeti Víztudományi Kutatási Program kihívásai és feladatai. Magyar Tudományos Akadémia, Ökológiai Kutatóközpont Víztudományi Koordinációs Csoport, 2018. Elérhető: https://mta.hu/data/dokumentumok/Viztudomanyi\%20Program/NVKP_20180331.pdf (A letöltés dátuma: 2020. 04. 04.)

UN Water [vízgazdálkodással foglalkozó szervezetek tevékenységét koordináló Egyesült Nemzetek Szövetségéhez tartozó alszervezet] Annual Report. 2013. Elérhető: www.unwater.org/publications/ un-water-annual-report-2013/ (A letöltés dátuma: 2020. 11. 24.)

Vízügyi és vízvédelemi hatósági tevékenység. Belügyminisztérium, Országos Katasztrófavédelmi Föigazgatóság. Elérhető: www.katasztrofavedelem.hu/130/vzgyi-s-vzvdelemi-hatsgi-tevkenysg (A letöltés dátuma: 2020. 04. 13.)

Vízrajzi monitoring az Országos Vízügyi Igazgatóság hatáskörében. 2015. Elérhető: www.ovf.hu/hu/ vizrajzi-monitoring (A letöltés dátuma: 2020. 04. 11.)

Vízügyi tervezés és kivitelezés. Tenderterv Kft. Elérhető: www.tenderterv.hu/ (A letöltés dátuma: 2020. 04. 13.) 